Article

\title{
Isolation and Identification of a New Tetrodotoxin-Producing Bacterial Species, Raoultella terrigena, from Hong Kong Marine Puffer Fish Takifugu niphobles
}

\author{
Vincent Chung-Him Yu ${ }^{1}$, Peter Hoi-Fu Yu ${ }^{1}$, Kin-Chung Ho ${ }^{2}$ and Fred Wang-Fat Lee ${ }^{2, *}$ \\ 1 Department of Applied Biology and Chemical Technology, The Hong Kong Polytechnic \\ University, Hong Kong, China; E-Mails: vincentyu@ymail.com (V.C.-H.Y.); \\ bcpyu@inet.polyu.edu.hk (P.H.-F.Y.)
}

2 School of Science and Technology, The Open University of Hong Kong, Hong Kong, China; E-Mail:kcho@ouhk.edu.hk

* Author to whom correspondence should be addressed; E-Mail: wflee@ouhk.edu.hk; Tel.: +852-2768-6868; Fax: +852-2789-1170.

Received: 24 September 2011; in revised form: 3 November 2011 / Accepted: 4 November 2011 / Published: 14 November 2011

\begin{abstract}
Puffer fish, Takifugu niphobles, collected from the Hong Kong coastal waters were screened for tetrodotoxin-producing bacteria. A Gram-negative, non-acid-fast, non-sporing and rod shaped bacterial strain (designated as gutB01) was isolated from the intestine of the puffer fish and was shown to produce tetrodotoxin (TTX). Based on the Microbial Identification (MIDI) and 16S-23S rDNA internal transcribed spacer (ITS) phylogenetic analysis, the strain was identified as Raoultella terrigena. The TTX production ability of the strain was confirmed by mouse bioassay, ELISA and mass spectrometry (MALDI-TOF). Our results reiterate that the TTX found in puffer fish was likely produced by the associated bacteria and TTX are widely produced amongst a diversity of bacterial species.
\end{abstract}

Keywords: tetrodotoxin; TTX-producing bacteria; Raoultella terrigena; Takifugu niphobles

\section{Introduction}

Tetrodotoxin (TTX), commonly known as puffer fish toxin, is one of the most lethal neurotoxins and is also known as the causative agent of puffer fish poisoning (PFP). Puffer fish is the most 
recognizable living organism that contains TTX. The amount of TTX in the puffer fish are species specific and varies among different organs in different seasons [1,2]. The origin of TTX in the TTX bearing organisms has been extensively studied in the case of puffer fish. It was reported that cultivated puffer fish above the sea bed or in an enclosed water system was found to be non-toxic, but they can become toxic when they were grown in open water again or were fed with toxic puffer livers [3]. These experimental findings suggested that TTX can be acquired and accumulated from the food chain in the higher level TTX bearing organism, like puffer fish. In addition, recent studies demonstrated that, besides puffer fish, TTX is widely distributed amongst a wide range of organisms and animals. Therefore, it has been suggested that TTX has an exogenous microbial origin, rather than being produced by puffer fishes per se [4].

TTX-producing bacteria have been isolated from various marine organisms and therefore they have been considered as one of the possible sources for TTX production in many TTX-bearing marine organisms [5-7]. Vibrio was the first reported TTX-producing bacterial strain isolated from the intestine of xanthid crab [5]. Thereafter, numerous bacterial strains with TTX producing ability were isolated and identified [4]. The number and types of TTX-producing bacterial strains have been increasing and most of the reported strains were belong to the genus Vibro, such as Vibrio alginolyticus isolated from puffer fish [8,9], starfish [10] and gastropod [11]. Other than the Vibro species, bacterial species including Pseudomonas spp., Bacillus spp., Aeromonas, Actinomyces, Serratia, Microbacterium, were other commonly found TTX producing species [7,9,12-16]. For the past two decades, more than 10 different TTX-producing bacterial strains have been isolated and identified from various organs of puffer fish (Table 1). The bacteria were mostly isolated from the ovary, liver and intestine, since these organs have been reported to be the most toxic tissues in various TTX-bearing organisms. Although there are more than 60 indigenous species of puffer fishes reported in China Sea [9], studies conducted to investigate the TTX-producing bacteria contained in local puffer fishes are very limited [9].

Table 1. Tetrodotoxin (TTX)-producing bacteria isolated from puffer fish from 1987-2011.

\begin{tabular}{lllc}
\hline Year & \multicolumn{1}{c}{ TTX-Producing Bacteria } & \multicolumn{1}{c}{ Origin of Isolation } & References \\
\hline 1987 & Pseudomonas species & Skin of Takifugu poecilonotus & {$[7]$} \\
1987 & Vibrio alginolyticus & Intestine of Takifugu vermicularis & {$[8]$} \\
1989 & Shewanella putrefaciens & Intestine of Takifugu niphobles & {$[16]$} \\
2000 & Vibrio species & Intestine of Takifugu vermicularis radiates & {$[17]$} \\
2004 & Microbacterium arabinogalactanolyticum & Ovary of Takifugu niphobles & {$[9]$} \\
2004 & Serratia marcescens & Skin of Chelonodon patoca & {$[9]$} \\
2004 & Vibrio alginolyticus & Intestine of Takifugu alboplumbeus & {$[9]$} \\
2005 & Actinomyces species & Ovary of Fugu rubripes & {$[18]$} \\
2005 & Bacillus species & Ovary, liver, and Intestine of Fugu rubripes & {$[18]$} \\
2005 & Nocardiopsis dassonillei & Ovary of Fugu rubripes & {$[19]$} \\
2007 & Proteobacteria, CFB group, and & Skin, intestine, ovary and liver of & {$[20]$} \\
2010 & Aeromonas species & Takifugu obscures & {$[21]$} \\
2010 & Bacillus species & Ovary of Takifugu obscures & {$[22]$} \\
2010 & Lysinibacillus fusiformis & Ovary of Fugu obscures & Liver of Fugu obscures \\
\hline & Raoultella terrigena & Intestine of Takifugu niphobles & (Present study) \\
\hline
\end{tabular}


The amount of TTX in puffer fish is not evenly distributed, but concentrated in several organs. In general, ovary and liver are believed to be the most toxic organs with the highest TTX level in puffer fish. However, the toxicity levels and the distribution of the toxin in different organs of puffer fish appear to be species specific. For example, it has been shown that the toxicity of the intestines of Japanese puffer fish Takifugu niphoble was comparable to the ovaries and livers, but far more potent than the other organs [15].

In the present study, we report a newly TTX-producing bacterial species, Raoultella terrigena, which was isolated from the intestines of a local toxic puffer fish Takifugu niphoble. The identity of the strain was investigated by MIDI and sequencing of the 16S-23S rDNA ITS region. Toxicity and TTX-producing ability of the strain were determined by mouse bioassay, ELISA and mass spectrometry. Analysis on the morphological and physiological characteristics of the strain was also performed.

\section{Results and Discussion}

\subsection{Bacterial Strain Isolation and Determination of TTX Production}

In the present study, we isolated totally five bacterial strains from the intestine of a local puffer fish Takifugu niphobles and assayed their toxicity. Mouse bioassay revealed that one of the strains, designated as gutB01, showed its ability to produce toxicity. Hence, further characterization of this strain was performed.

In the mouse bioassay, mice injected with the toxin extracted from gutB01 showed typical symptoms of TTX intoxication, such as convulsions and dyspnea, and were killed within 10 to $15 \mathrm{~min}$. The toxicity of gutB01 determined by the mouse bioassay was $7.7 \mu \mathrm{g} / \mathrm{L}$ and $4.2 \mu \mathrm{g} / \mathrm{L}$ of cells cultivated for $24 \mathrm{~h}$ and $48 \mathrm{~h}$ respectively (Table 2). ELISA methods have been successfully demonstrated to determine the presence of TTX in bacteria isolated from the gastropod $N$. semiplicatus and ovary of puffer fish Takifugu obscures previously [21,24]. Here, this competitive ELISA method was used to further determine the TTX production from the strain gutB01. The standard curve established in the experiment with a $R^{2}$ value 0.985 showed a good linearity relationship between absorbance signal and the TTX concentration within the range of $0-100 \mathrm{ng} / \mathrm{mL}$ (data not shown). The TTX concentration of the strain gutB01 that cultivated for $24 \mathrm{~h}$ was $4.3 \mu \mathrm{g} / \mathrm{L}$ and it was calculated by the regression equation derived from the standard curve $(y=-0.049 \operatorname{In}(x)+0.006)$. There was a discrepancy between the results obtained from the mouse bioassay and ELISA. The presence of some unidentified toxic components, or TTX derivatives may contribute to the higher toxicity observed in the mouse bioassay. Furthermore, the toxicity of cells cultured for $24 \mathrm{~h}$ is two-fold higher than that of the cells cultured for $48 \mathrm{~h}$ (Table 2). The differences in toxicity might be attributed to the different growth phases of the cells. As indicated from the growth curve, the cells cultured for $24 \mathrm{~h}$ were in $\log$ phase and the cells cultured for $48 \mathrm{~h}$ were in stationary phase. However, further studies are required to determine the effects of different growth phases/conditions to the toxicity of the bacterial cells.

Mass spectrometry, such as ESI-MS, ESI-Q-TOF MS and MALDI-TOF MS, has been used extensively to detect the presence of TTX in suspected organisms. For example, the occurrence of TTX in the Brazilian frog Brachycephalus ephippium was demonstrated by MALDI-TOF MS 
previously [25]. The chemical identity of putative TTX purified from the isolated strain gutB01 was further analyzed by MALDI-TOF MS (Figure 1). In a positive detection mode, a distinctive peak ion at $\mathrm{m} / z 320.2[\mathrm{M}+\mathrm{H}]^{+}$was observed in both TTX standard and toxin purified from strain gutB01. Such protonated molecular ion $\left(320.2[\mathrm{M}+\mathrm{H}]^{+}\right)$was compatible to the corresponding molecular mass of TTX (319 Da). Since the corresponding peak mass ion at $m / z 320.2[\mathrm{M}+\mathrm{H}]^{+}$was only observed in the standard and gutB01 toxin sample but not the non-toxic bacterial isolate and the matrix per se, we believe the putative TTX in the toxin sample purified from the cultured strain gutB01 could most likely be identified as authentic tetrodotoxin. Although we were not able to determine the presence of TTX analogues due to the lack of the corresponding toxin reference standards, toxicity results obtained from the three assays allowed us to believe that strain gutB01 bears TTX-producing ability.

Figure 1. MALDI-TOF mass spectra of toxin extract isolated from gutB01. Only the TTX standard and sample of gutB01 exhibited the mass of $320.2 \mathrm{Da}[\mathrm{M}+\mathrm{H}]^{+}$(corresponding to the mass of protonated ion of TTX), but not the matrix and toxin extract from a non-toxic bacterial clone.

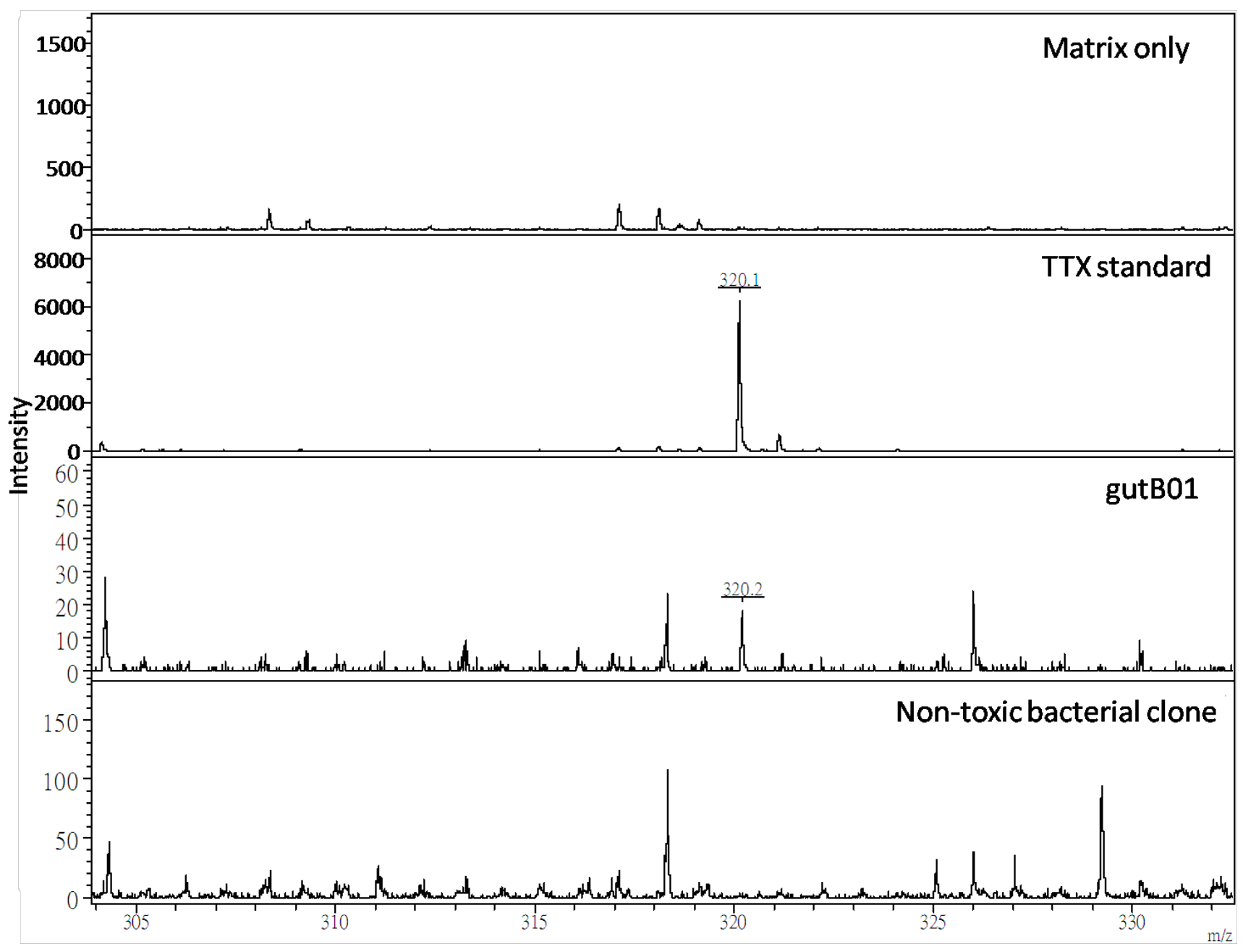


Table 2. Toxicity and the MIDI result of gutB01.

\begin{tabular}{ll}
\hline & Raoultella terrigena (gutB01) \\
\hline Culture medium (time for cultivation) & ORI $(24 \mathrm{~h})$ \\
Mouse bioassy $(\mathrm{MU} / \mathrm{L})$ & 38.5 \\
Mouse bioassy $(\mu \mathrm{g} / \mathrm{L})$ & 7.7 \\
ELISA ( $\mu \mathrm{g} / \mathrm{L})$ & 4.3 \\
Culture medium (time for cultivation) & ORI $(48 \mathrm{~h})$ \\
Mouse bioassy (MU/L) & 21.1 \\
Mouse bioassy ( $\mu \mathrm{g} / \mathrm{L})$ & 4.2 \\
ELISA ( $\mu \mathrm{g} / \mathrm{L})$ & $\mathrm{N}^{+} \mathrm{A}^{+}$ \\
\hline MIDI Similarity index & 0.906 \\
\hline${ }^{\#}$ According to The Sherlock ${ }^{\circledR}$ Microbial Identification System (MIDI System) manual, strains with \\
a similarity of 0.600 or higher is considered good library comparisons. If the similarity index is \\
between 0.400 and 0.600, it may be a good match but an atypical strain. Values lower than 0.400 \\
suggest that the system does not have the species in the database, but indicate the most closely \\
related species. ${ }^{+}$Data not available.
\end{tabular}

\subsection{Identification and Phylogenetic Analysis of Strain GutB01}

Strain gutB01 was subjected to the MIDI analysis (Table 2), which has been one of the most common methods used for microbial identification. The basic principle of this method is to match the fatty acid profile of the unknown species to the fatty acid profiles of various reference microbial species in a database. The MIDI results showed that the bacterial isolate gutB01 was Raoultella terrigena, with high similarity index 0.906 (similarity index 1.00 indicates the exact match of the fatty acid profiles between the sample and suggested strain in the database).

For the past decades, phylogenetic and species identification studies based on 16S-23S rDNA ITS sequences have begun to appear more frequently in the literature and is becoming one of the most important tools for bacterial species identification [26,27]. Such a sequence was chosen in the molecular analysis of gutB01, because this region provides a more accurate representation of microbial genotypes. For example, a previous study to analyze the 16S-23S rDNA ITS sequences of Klebsiella species reveals that the ITS region bear sufficient variations to allow differentiation between the bacterial species [28]. The sequence obtained in our study was searched against the NCBInr database through the BLAST program. The species with the most similar sequences (99\% identical) resulted from the searches was Raoultella terrigena (CCM3568, Accession no. EU623235). When the ITS sequence of Raoultella terrigena aligned with the corresponding sequence of gutB01 (Figure 2), there were only $1.3 \%$ of mismatched nucleotides or gaps found between the two sequences. Followed by the sequence analysis, we performed phylogenetic analysis based on the 16S-23S rDNA ITS sequences (Figure 3). Although the results may be affected due to the lack of other Raoultella (Klebsiella) sequences data available for the phylogenetic analysis, the tree clearly showed that the strain gutB01 fall within the cluster comprising the members of genus Raoultella (Klebsiella) and was closest to the species Raoultella terrigena. 
Figure 2. 16S-23S rDNA ITS sequences of the strain gutB01. The most similar sequence obtained from bioinformatic search against the NCBInr database was the sequence from Raoultella terrigena (CCM3568, Accession no. EU623235). The alignment of both sequences and their differences are shown (nucleotides highlighted with dotted lines). There are 7 mismatches/gaps between these two sequences (with 542 nucleotides).

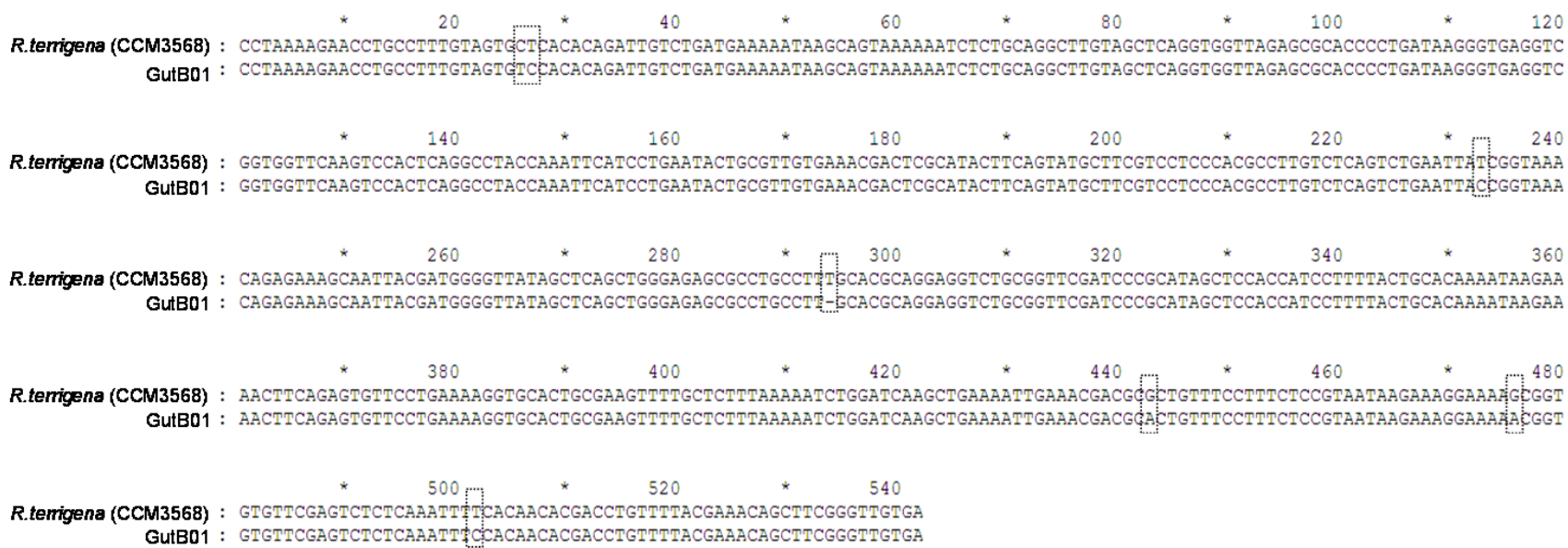

Figure 3. Neighbor-joining tree showing the phylogenetic relationship of the present strain gutB01 with other Raoultella (Klebsiella) species based on the ITS (16S-23S rDNA ITS) sequences. The numbers represent the percentage of 1000 replications (bootstrap support) for which the same branching patterns were obtained. Pseudomonas aeruginosa (JN628283) is employed as the outgroup reference. NCBI accession numbers of the ITS sequences used for the study are EU623235 (Raoultella terrigena), EU623088 (Raoultella planticola), EU623097 (Raoultella ornithinolytica), DQ470481 (Raoultella sp.), EU623278 (Klebsiella pneumonia subsp. pneumoniae), and EU623328 (Klebsiella oxytoca). The scale bar indicates $1 \%$ divergence.

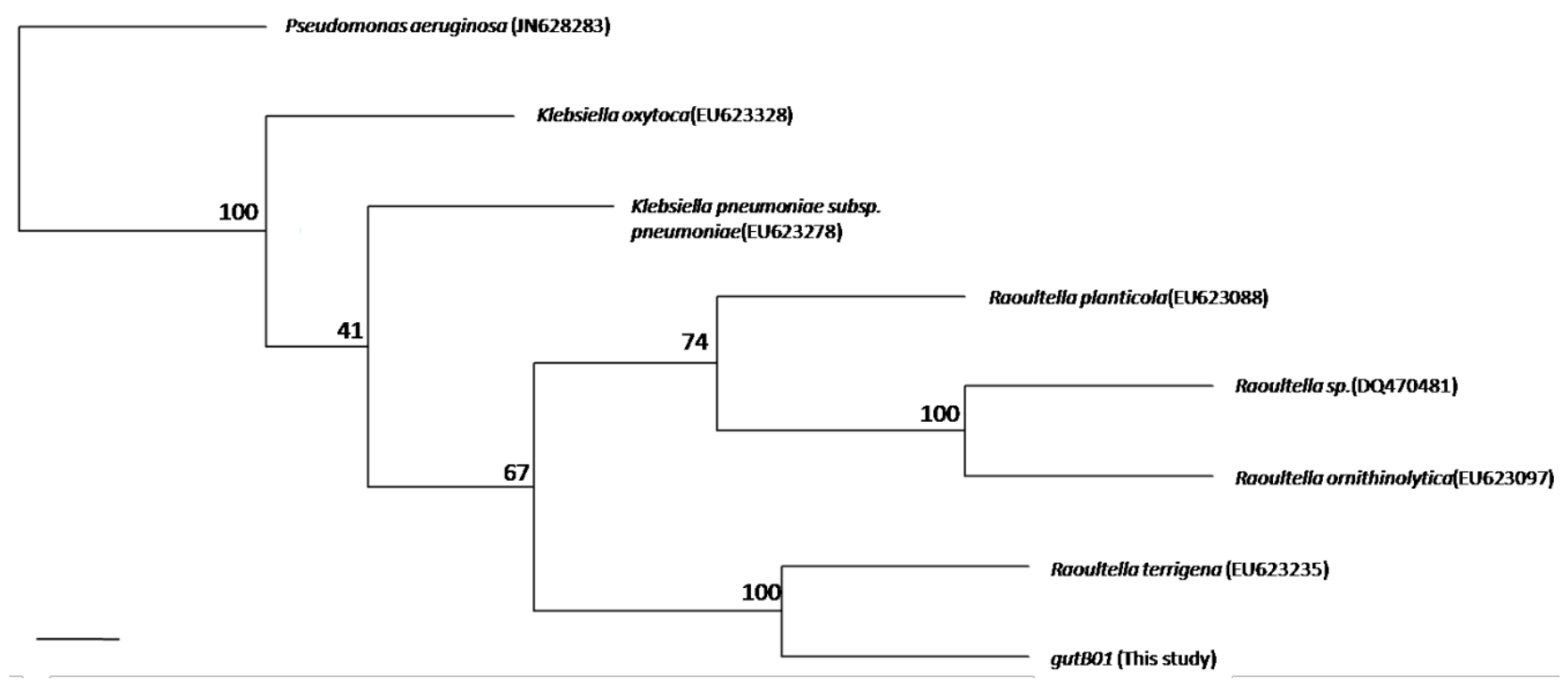




\subsection{Morphological and Physiological Characteristics of Strain GutB01}

Based on the morphological and physiological analyses (Table 3), the bacterial strain gutB01 was found to be non-sporing, non acid-fast and Gram-negative rod shaped. The colonies of the strain were circular, convex, and had a diameter of between 2 and $4.5 \mathrm{~mm}$. Growth was observed between $20{ }^{\circ} \mathrm{C}$ and $37{ }^{\circ} \mathrm{C}, 0 \%$ and $3 \% \mathrm{NaCl}, \mathrm{pH} 7$ and 9 . The growth curve of the strain gutB01 is shown in Figure 4. As can be seen from the curve, the strain reached the end of the log phase after $24 \mathrm{~h}$ incubation.

All in all, based on all these data obtained, along with the data from the MIDI analysis, sequence alignment of the 16S-23S rDNA ITS as well as phylogenetic analysis of the species presented in the study, suggests that the present toxic strain gutB01 was identified as Raoultella terrigena.

Table 3. Morphological and physiological characteristics of Raoultella terrigena.

\begin{tabular}{|c|c|}
\hline Characteristic $^{\#}$ & Raoultella Terrigena * (gutB01) \\
\hline Colony diameter (mm) & $2-4.5$ \\
\hline Shape of colonies & Circular \\
\hline Elevation of colony & Convex \\
\hline Colony margin & Entire \\
\hline Cell shape & Rod \\
\hline Cell width $(\mu \mathrm{m})$ & $0.5-0.8$ \\
\hline Cell length $(\mu \mathrm{m})$ & $0.5-0.8$ \\
\hline Gram stain & - \\
\hline Acid-fast stain & - \\
\hline Spore Formation & - \\
\hline \multicolumn{2}{|l|}{ Growth at } \\
\hline $20^{\circ} \mathrm{C}$ & + \\
\hline $25^{\circ} \mathrm{C}$ & + \\
\hline $30{ }^{\circ} \mathrm{C}$ & + \\
\hline $37^{\circ} \mathrm{C}$ & + \\
\hline \multicolumn{2}{|l|}{ Growth in $\mathrm{NaCl}$ of } \\
\hline $0 \%$ & + \\
\hline $3 \%$ & $+($ little $)$ \\
\hline $5 \%$ & - (decrease steadily) \\
\hline $7 \%$ & - (decrease steadily) \\
\hline $10 \%$ & - (none) \\
\hline \multicolumn{2}{|l|}{ Growth at $\mathrm{pH}$} \\
\hline 5 & - \\
\hline 6 & - \\
\hline 7 & + \\
\hline 8 & + \\
\hline 9 & + \\
\hline
\end{tabular}

\# The characteristics were measured as described previously [9]. * Other typical phe
characteristics of Raoultella terrigena are described in [29]. +: positive; -: negative. 
Figure 4. Growth curve of bacterial strain gutB01. The growth was monitored through optical density measurement of culture medium at wavelength $600 \mathrm{~nm}$.

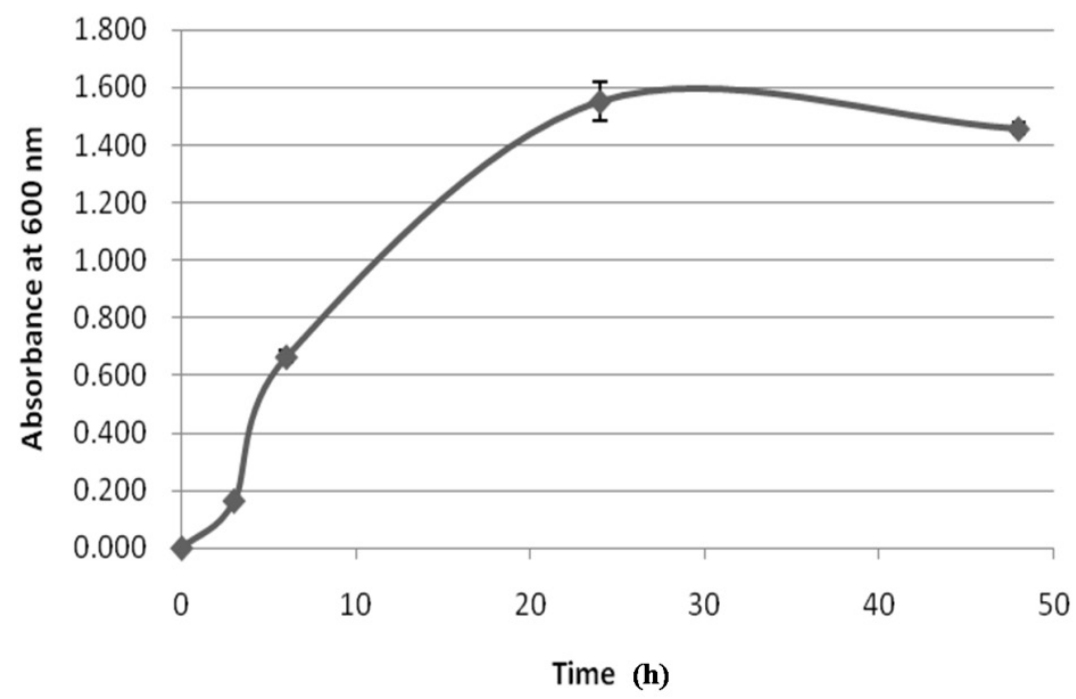

\section{Experimental Section}

\subsection{Puffer Fish Samples and Collection}

Specimens of puffer fish Takifugu niphobles were collected along the Hong Kong coastal waters in January 2006. The collected specimens were kept alive and transported to the laboratory. Various organs including the intestine of each fish were sampled aseptically for bacteriological examination and toxicity assay.

\subsection{Bacterial Culture Medium and Agar Plates}

Sterilized Ocean Research Institute (ORI) medium was used for culturing bacteria [30], which contained (in gram per liter) protease peptone No. 3 (Difco), 2 g; Bacto-yeast extract (Difco), 2 g; Phytone peptone (BBL), $1 \mathrm{~g}$; sodium thiosulphate, $0.4 \mathrm{~g}$; sodium sulphite, $1 \mathrm{~g}$; iron citrate, $0.08 \mathrm{~g}$; seawater, $750 \mathrm{~g}$ and adjusted to $\mathrm{pH}$ 7.6, with sodium hydroxide or hydrochloric acid. The ORI agar plates were prepared with $15 \mathrm{~g}$ of agar dissolved in $1 \mathrm{~L}$ of ORI medium.

\subsection{Bacterial Isolation}

Bacteria were extracted from the puffer fish intestine by adding $10 \mathrm{~mL}$ of Phosphate Buffered Saline (PBS) to $2 \mathrm{~g}$ of target organ. The tissue extract was prepared by blending the tissue for $1 \mathrm{~min}$ with homogenizer in ice bath. Tissue residue and fat were filtered off and subjected to serial dilutions $\left(10^{-1}\right.$ and $\left.10^{-2}\right)$ using PBS. $100 \mu \mathrm{L}$ of each diluted sample inoculated to the ORI agars using streak plate method. The plates were maintained at $30{ }^{\circ} \mathrm{C}$ for $3-5$ days to allow bacterial growth. Each discrete colony was further subcultured for several times to ensure that it was a pure culture before subjected to the toxicity test and bacterial identification. 


\subsection{Extraction and Purification of TTX}

The extraction and purification of TTX from the samples were described previously [9]. Briefly, the cultures grown for 24 or $48 \mathrm{~h}$ were centrifuged at $8000 \mathrm{rpm}$ for $30 \mathrm{~min}$ to remove the bacterial cells. The supernatant was collected and evaporated in reduced pressure to concentrate, which was then added to pre-washed activated charcoal under agitation and filtered through a Buchner funnel with autoclaved cheesecloth. The charcoal on the funnel was thoroughly washed with distilled water and $1 \%$ acetic acid in $20 \%$ aqueous ethanol was used to elute the adsorbed TTX. The eluate was concentrated and subjected to gel-filtration through a column of Bio-Gel ${ }^{\circledR}$ P-2 (Bio-Rad Laboratories) which was equilibrated with $0.03 \mathrm{M}$ acetic acid. Toxic fractions were then combined and subjected to cation exchange chromatography through a column of Bio-Rex ${ }^{\circledR} 70$ ( $\mathrm{H}^{+}$form, Bio-Rad Laboratories). The TTX was eluted by a linear gradient using $0-0.03 \mathrm{M}$ acetic acid. Toxic fractions were combined and concentrated for further toxicity bioassay and detection of TTX.

\subsection{Assays for TTX}

\subsubsection{Mouse Bioassay}

Mouse bioassay was performed as described [9]. Briefly, healthy mice (Institute of Cancer Research, ICR) which weighed between 15-25 g were used in the mouse bioassay. Toxin samples used in the mouse bioassay are purified by $0.2 \mu \mathrm{m}$ syringe filter before the injection. A group of 4-6 mice were chosen randomly and $1 \mathrm{~mL}$ of toxin sample was injected intraperitoneally into the mice. The death time was recorded at the last grasping breath of the mouse. Lethal potency of TTX was expressed in mouse units (MU), one MU was defined as the amount of toxin required to kill a $20 \mathrm{~g}$ ICR strain mouse in $30 \mathrm{~min}$ after intraperitoneal injection and specific toxicity of pure TTX is (5000 MU/mg).

\subsubsection{Enzyme-Linked Immunosorbent Assay (ELISA)}

The ELISA kit used in the present study was kindly provided by The Institute of Food Quality and Safety, South China Agriculture University, Guangzhou [31]. For the preparation of the ELISA plate, $2 \mu \mathrm{g} / \mathrm{mL}$ TTX-OVA coating antigen was coated to microplate with coating solution for about $18 \mathrm{~h}$ and the residual liquid was tapped out. $200 \mu \mathrm{L}$ blocking solution (5\% skimmed milk powder in PBS) was then used to mask the uncoated region and prevent the non-specific binding. It was followed by washing with washing buffer PBST (PBS with 0.05\% Tween-20) for 5 times after $2 \mathrm{~h}$ incubation. To detect TTX concentration in the samples, $50 \mu \mathrm{L}$ diluted peroxidase conjugated antibody (diluted with PBST with $1 \%$ BSA) into each well following by adding $50 \mu \mathrm{L}$ TTX standard or sample into the wells (diluted with PBST if needed). The microplate was incubated for $30 \mathrm{~min}$ at room temperature. Washing step was repeated and $100 \mu \mathrm{L}$ TMB (3,3',5,5'-Tetramethylbenzidine) substrate solution was added into each well and incubated at $37{ }^{\circ} \mathrm{C}$ for $15 \mathrm{~min} .50 \mu \mathrm{L}$ stopping solution ( $2 \mathrm{M}$ sulfuric acid) was then added into each well to stop the reaction. The absorbance was measured at wavelength $450 \mathrm{~nm}$ and the well with PBST was used as blank. Standard curve was constructed with standard TTX at the concentration range of $0-100 \mathrm{ng} / \mathrm{mL}$. TTX concentration of the sample was calculated based on the standard curve. 


\subsubsection{Mass Spectrometry}

The toxin samples were analyzed by MALDI-TOF mass spectrometry (Autoflex III, Bruker, Germany). $1 \mu \mathrm{L}$ of sample solution were mixed with $1 \mu \mathrm{L}$ of matrix solution. The resulting mixtures were then vortexed before spotting $0.5 \mu \mathrm{L}$ volume onto a mass spectrometer target plate (MTP AnchorChip $^{\mathrm{TM}}$ 600/384) (Bruker, Germany). Sample mixtures were crystallized at room temperature, and their masses analyzed in reflectron mode at an accelerating voltage of $20 \mathrm{kV}$ by using a $100 \mathrm{~ns}$ delay time over a mass range of 100-1000 Da using external mass calibration with calibration standards from the manufacturer. Matrix alone and a non-toxic bacterial clone isolated from the same puffer fish were used as control.

\subsection{Identification of TTX Producing Bacteria}

\subsubsection{MIDI Identification System}

Isolated bacteria were characterized using The Sherlock ${ }^{\circledR}$ Microbial Identification System (MIS) (MIDI, Inc., Newark, Delaware, USA), which identifies bacteria by comparison of the whole cell fatty acid profiles between the samples and the system's database, using gas chromatography analysis.

\subsubsection{S-23S ITS DNA Sequencing and Phylogenetic Analysis}

Genomic DNA of the isolated bacteria was extracted by a DNA extraction kit (Roche, Switzerland) following mechanical cell disruption by a quick homogenization. 16S-23S rDNA ITS region was amplified from the extracted DNA using PCR with the primers Raou-ITSF: 5'-CCTRAAAGAACCTGCCTTTGTAG-3' and Raou-ITSR: 5'-TCACAACCCGAARCTGTTTCGTA-3'. PCR were performed under conditions: $95{ }^{\circ} \mathrm{C} 5 \mathrm{~min} ; 35$ cycles of $94{ }^{\circ} \mathrm{C} 45 \mathrm{~s}, 55{ }^{\circ} \mathrm{C} 45 \mathrm{~s}$ and $72{ }^{\circ} \mathrm{C}$ $2 \mathrm{~min} ; 72{ }^{\circ} \mathrm{C} 10 \mathrm{~min}$. PCR products were cloned into pGEM-T easy vectors (Promega, USA) prior to DNA sequencing. DNA sequencing of all cloned plasmids were performed by commercial facilities using traditional dideoxy-methodolgy. The 16S-23S rDNA ITS sequence was compared with sequences in the NCBI GenBank database using the BLAST program.

For phylogenetic analysis, the ITS sequence of gutB01 was aligned and compared with the corresponding sequences of other Raoultella species available from PubMed by using the Clustal X program [32]. Phylogenetic analysis was carried out using PHYLIP, version 3.69 (Joe Felsenstein, Department of Genetics, University of Washington). Distance matrices were produced using the DNADIST module according to the two-parameter model of kimura [33] and building a Neighbor-Join tree with the NEIGHBOR module. One thousand bootstrap replicates were generated and performed using the SEQBOOT module and the consensus tree was generated using CONSENSE. Tree was viewed with the Treeview software [34].

\section{Conclusions}

The present study revealed for the first time that a novel TTX-producing bacteria species, Raoultella terrigena, was isolated from the toxic puffer fish Takifugu niphobles collected from Hong Kong coastal waters. This further suggested that the toxin found in puffer fish was likely produced by 
the associated bacteria. However, more research is still required to elucidate the mechanism of the synthesis of TTX by bacteria, as well as their role in toxin production. In addition, our study could not exclude the possibility that other bacteria in the puffer fish T. niphobles may also produce TTX.

\section{Acknowledgments}

The authors thank the anonymous referees for reviewing the manuscript and the comments suggested.

\section{References}

1. Yu, C.F.; Yu, P.H.F. Are puffer fish more toxic in their spawning seasons? Mar. Biol. 2002, 140, 1053-1057.

2. Yu, C.F.; Yu, P.H.F. The annual toxicological profiles of two common puffer fish, Takifugu niphobles (Jordan and Snyder) and Takifugu alboplumbeus (Richardson), collected along Hong Kong coastal waters. Toxicon 2002, 40, 313-316.

3. Shimizu, Y. Chemistry and Biochemistry of Saxitoxin Analogues and Tetrodotoxin. In Tetrodotoxin, Saxitoxin, and the Molecular Biology of the Sodium Channel; Kao, C.Y., Levinson, S.R., Eds.; Academy of Sciences: New York, NY, USA, 1986; Volume 479, pp. 24-30.

4. Miyazawa, K.; Noguchi, T. Distribution and origin of tetrodotoxin. J. Toxicol. Toxin. Rev. 2001, 20, 11-33.

5. Noguchi, T.; Jeon, J.K.; Arakawa, O.; Sugita, H.; Deguchi, Y.; Shida, Y.; Hashimoto, K. Occurrence of tetrodotoxin and anhydrotetrodotoxin in Vibrio sp. isolated from the intestines of a xanthid crab, Atergatis floridus. J. Biochem. 1986, 99, 311-314.

6. Yasumoto, T.; Yasumura, D.; Yotsu, M.; Michishita, T.; Endo, A.; Kotaki, Y. Bacterial production of tetrodotoxin and anhydrotetrodotoxin. Agric. Biol. Chem. 1986, 50, 793-795.

7. Yotsu, M.; Yamazaki, T.; Meguro, Y.; Endo, A.; Murata, M.; Naoki, H.; Yasumoto, T. Production of tetrodotoxin and its derivatives by Pseudomonas sp. isolated from the skin of a pufferfish. Toxicon 1987, 25, 225-228.

8. Noguchi, T.; Hwang, D.F.; Arakawa, O.; Sugita, H.; Deguchi, Y.; Shida, Y.; Hashimoto, K. Vibrio alginolyticus, a tetrodotoxin-producing bacterium, in the intestine of the fish Fugu vermicularis vermicularis. Mar. Biol. 1987, 94, 625-630.

9. Yu, C.F.; Yu, P.H.; Chan, P.L.; Yan, Q.; Wong, P.K. Two novel species of tetrodotoxin-producing bacteria isolated from toxic marine puffer fishes. Toxicon 2004, 44, 641-647.

10. Narita, H.; Matsubara, S.; Miwa, N.; Akahane, S.; Murakami, M.; Goto, T.; Nara, M.; Noguchi, T.; Saito, T.; Shida, Y.; et al. Vibrio alginolyticus, A TTX-Producing bacterium isolated from the starfish Astropecten polyacanthus. Bull. Jpn. Soc. Sci. Fish. 1987, 53, 617-621.

11. Cheng, C.A.; Hwang, D.F.; Tsai, Y.H.; Chen, H.C.; Jeng, S.S.; Noguchi, T.; Ohwada, K.; Hashimoto, K. Microflora and tetrodotoxin-producing bacteria in a gastropod, Niotha clathrata. Food Chem. Toxicol. 1995, 33, 929-934.

12. Do, H.K.; Hamasaki, K.; Ohwada, K.; Simidu, U.; Noguchi, T.; Shida, Y.; Kogure, K. Presence of tetrodotoxin and tetrodotoxin-producing bacteria in fresh-water sediments. Appl. Environ. Microbiol. 1993, 59, 3934-3937. 
13. Do, H.K.; Kogure, K.; Imada, C.; Noguchi, T.; Ohwada, K.; Simidu, U. Tetrodotoxin production of actinomycetes isolated from marine sediment. J. Appl. Bacteriol. 1991, 70, 464-468.

14. Hwang, D.F.; Arakawa, O.; Saito, T.; Noguchi, T.; Simidu, U.; Tsukamoto, K.; Shida, Y.; Hashimoto, K. Tetrodotoxin-producing bacteria from the blue-ringed octopus Octopus maculosus. Mar. Biol. 1989, 100, 327-332.

15. Noguchi, T.; Arakawa, O.; Takatani, T. TTX accumulation in pufferfish. Comp. Biochem. Physiol. D Genomics Proteomics 2006, 1, 145-152.

16. Matsui, T.; Taketsugu, S.; Kodama, K.; Ishii, A.; Yamamori, K.; Shimizu, C. Production of tetrodotoxin by the intestinal bacteria of a puffer fish Takifugu niphobles. Nippon Suisan Gakkaishi 1989, 55, 2199-2203.

17. Lee, M.J.; Jeong, D.Y.; Kim, W.S.; Kim, H.D.; Kim, C.H.; Park, W.W.; Park, Y.H.; Kim, K.S.; Kim, H.M.; Kim, D.S. A tetrodotoxin-producing Vibrio strain, LM-1, from the puffer fish Fugu vermicularis radiatus. Appl. Environ. Microbiol. 2000, 66, 1698-701.

18. Wu, Z.; Yang, Y.; Xie, L.; Xia, G.; Hu, J.; Wang, S.; Zhang, R. Toxicity and distribution of tetrodotoxin-producing bacteria in puffer fish Fugu rubripes collected from the Bohai Sea of China. Toxicon 2005, 46, 471-476.

19. Wu, Z.; Xie, L.; Xia, G.; Zhang, J.; Nie, Y.; Hu, J.; Wang, S.; Zhang, R. A new tetrodotoxin-producing actinomycete, Nocardiopsis dassonvillei, isolated from the ovaries of puffer fish Fugu rubripes. Toxicon 2005, 45, 851-859.

20. Yang, G.; Bao, B.; Peatman, E.; Li, H.; Huang, L.; Ren, D. Analysis of the composition of the bacterial community in puffer fish Takifugu obscurus. Aquaculture 2007, 262, 183-191.

21. Yang, G.; Xu, J.; Liang, S.; Ren, D.; Yan, X.; Bao, B. A novel TTX-producing Aeromonas isolated from the ovary of Takifugu obscurus. Toxicon 2010, 56, 324-329.

22. Wang, J.; Fan, Y. Isolation and characterization of a Bacillus species capable of producing tetrodotoxin from puffer fish Fugu obscurus. World J. Microbiol. Biotechnol. 2010, 26, 1755-1760.

23. Wang, J.; Fan, Y.; Yao, Z. Isolation of a Lysinibacillus fusiformis strain with tetrodotoxin-producing ability from puffer fish Fugu obscurus and the characterization of this strain. Toxicon 2010, 56, 640-643.

24. Wang, X.J.; Yu, R.C.; Luo, X.; Zhou, M.J.; Lin, X.T. Toxin-screening and identification of bacteria isolated from highly toxic marine gastropod Nassarius semiplicatus. Toxicon 2008, 52, $55-61$.

25. Pires, O.R., Jr.; Sebben, A.; Schwartz, E.F.; Largura, S.W.; Bloch, C., Jr.; Morales, R.A.; Schwartz, C.A. Occurrence of tetrodotoxin and its analogues in the Brazilian frog Brachycephalus ephippium (Anura: Brachycephalidae). Toxicon 2002, 40, 761-766.

26. Conrads, G.; Claros, M.C.; Citron, D.M.; Tyrrell, K.L.; Merriam, V.; Goldstein, E.J.C. 16S-23S rDNA internal transcribed spacer sequences for analysis of the phylogenetic relationships among species of the genus Fusobacterium. Int. J. Syst. Evol. Microbiol. 2002, 52, 493-499.

27. Brown, M.V.; Fuhrman, J.A. Marine bacterial microdiversity as revealed by internal transcribed spacer analysis. Aquatic. Microbial. Ecol. 2005, 41, 15-23.

28. Wang, M.; Cao, B.; Yu, Q.; Liu, L.; Gao, Q.; Wang, L.; Feng, L. Analysis of the 16S-23S rRNA gene internal transcribed spacer region in Klebsiella species. J. Clin. Microbiol. 2008, 46, 3555-63. 
29. Drancourt, M.; Bollet, C.; Carta, A.; Rousselier, P. Phylogenetic analyses of Klebsiella species delineate Klebsiella and Raoultella gen. nov., with description of Raoultella ornithinolytica comb. nov., Raoultella terrigena comb. nov. and Raoultella planticola comb. nov. Int. J. Syst. Evol. Microbiol. 2001, 51, 925-932.

30. Simidu, U.; Tsukamoto, K. Habitat segregation and biochemical activities of marine members of the family vibrionaceae. Appl. Environ. Microbiol. 1985, 50, 781-790.

31. Liu, Y.; Zhong, Q.; Lei, H.; Zhang, T.; Yu, H.F.; Sun, Y.M. Study on the antibody against tetrodotoxin made by the immunogen with different carrier proteins. Wei Sheng Yan Jiu 2008, 37, 234-236.

32. Thompson, J.D.; Gibson, T.J.; Plewniak, F.; Jeanmougin, F.; Higgins, D.G. The Clustal_X windows interface: Flexible strategies for multiple sequence alignment aided by quality analysis tools. Nucleic Acids Res. 1997, 25, 4876-4882.

33. Kimura, M. A simple method for estimating evolutionary rates of base substitutions through comparative studies of nucleotide-sequences. J. Mol. Evol. 1980, 16, 111-120.

34. Page, R.D. TreeView: An application to display phylogenetic trees on personal computers. Comput. Appl. Biosci. 1996, 12, 357-358.

Samples Availability: Available from the authors.

(C) 2011 by the authors; licensee MDPI, Basel, Switzerland. This article is an open access article distributed under the terms and conditions of the Creative Commons Attribution license (http://creativecommons.org/licenses/by/3.0/). 